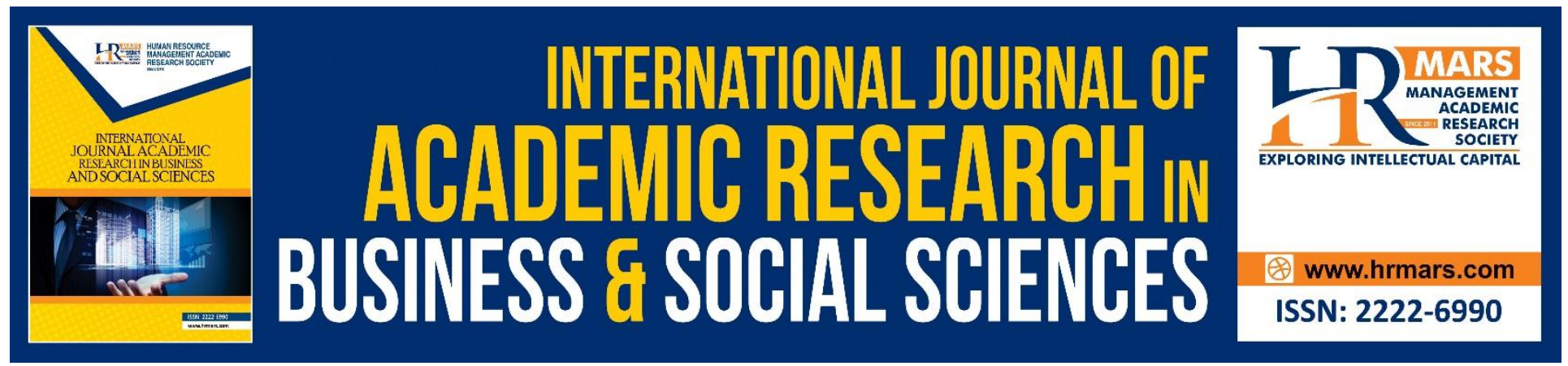

\title{
Islamic Spiritual Ethics and Postmodernist Moral Thought: Can There Be A Reconciliation?
}

Adibah Sulaiman, Hisham Muhammad Taky Eldin Kandil, Mohd. Azmir Mohd. Nizah, Ahmad Norsyafwan Norawavi \& Ezad Azraai Jamsari

To Link this Article: http://dx.doi.org/10.6007/IJARBSS/v9-i1/5466

DOI: $\quad 10.6007 /$ IJARBSS/v9-i1/5466

Received: 07 Jan 2019, Revised: 23 Jan 2019, Accepted: 11 Feb 2019

Published Online: 15 Feb 2019

In-Text Citation: (Sulaiman, Kandil, Nizah, Norawavi, \& Jamsari, 2019)

To Cite this Article: Sulaiman, A., Kandil, H. M. T. E., Nizah, M. A. M., Norawavi, A. N., \& Jamsari, E. A. (2019). Islamic Spiritual Ethics and Postmodernist Moral Thought: Can There Be A Reconciliation? International Journal of Academic Research in Business and Social Sciences, 9(1), 670-683.

Copyright: (c) 2019 The Author(s)

Published by Human Resource Management Academic Research Society (www.hrmars.com)

This article is published under the Creative Commons Attribution (CC BY 4.0) license. Anyone may reproduce, distribute, translate and create derivative works of this article (for both commercial and non-commercial purposes), subject to full attribution to the original publication and authors. The full terms of this license may be seen at: http://creativecommons.org/licences/by/4.0/legalcode

Vol. 9, No. 1, 2019, Pg. 670 - 683

http://hrmars.com/index.php/pages/detail/IJARBSS

JOURNAL HOMEPAGE

Full Terms \& Conditions of access and use can be found at http://hrmars.com/index.php/pages/detail/publication-ethics 


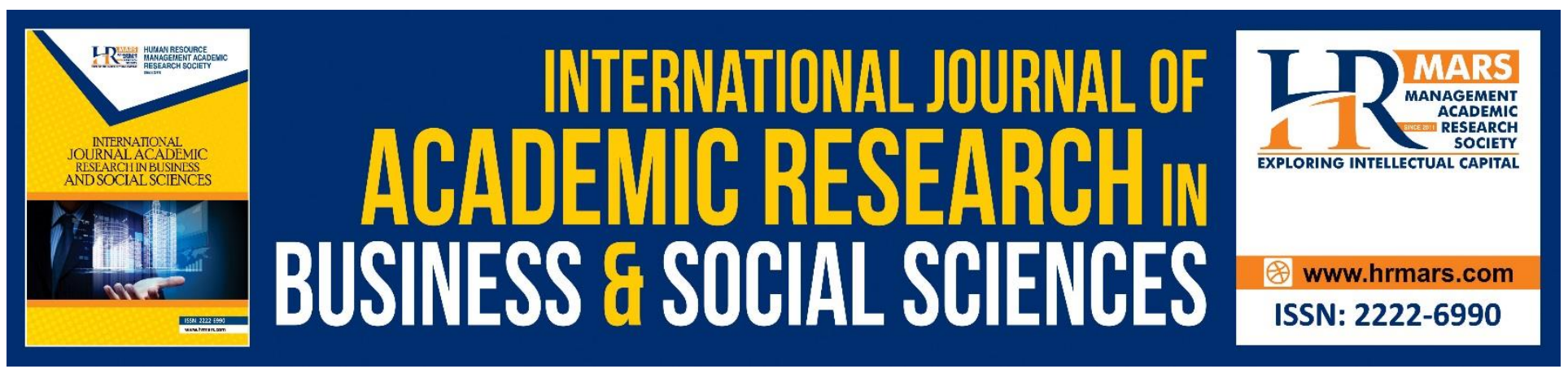

\title{
Islamic Spiritual Ethics and Postmodernist Moral Thought: Can There Be A Reconciliation?
}

\author{
${ }^{1,2}$ Adibah Sulaiman, ${ }^{1,2}$ Hisham Muhammad Taky Eldin Kandil, \\ 1,3Mohd. Azmir Mohd. Nizah, \\ ${ }^{1}$ Ahmad Norsyafwan Norawavi \& ${ }^{4}$ Ezad Azraai Jamsari \\ ${ }^{1}$ Centre for Core Studies, Universiti Sains Islam Malaysia, 71800 Bandar Baru Nilai, Negeri Sembilan, \\ Malaysia \\ ${ }^{2}$ Faculty of Major Language Studies, Universiti Sains Islam Malaysia, 71800 Bandar Baru Nilai, Negeri \\ Sembilan, Malaysia \\ ${ }^{3}$ Faculty of Leadership and Management, Universiti Sains Islam Malaysia, 71800 Bandar Baru Nilai, \\ Negeri Sembilan, Malaysia \\ ${ }^{4}$ Centre for The Middle East and Nusantara, Faculty of Islamic Studies, Universiti Kebangsaan \\ Malaysia, 43600 UKM Bangi, Selangor, Malaysia \\ *Corresponding Author: eajsti@gmail.com
}

\begin{abstract}
Postmodern ethical thought is not in line with Islamic spiritual ethics as modernism and postmodernism are Western ideas that have no place in Islam. This library study briefly elaborates the history of ethical development in the Islamic world and the spiritual ethics from the Islamic perspective. It also surveys the thought of postmodernism as well as postmodernism and religion as they need some deliberation for the interrelation between religion and ethics. As far as spiritual ethical thoughts are concerned, a discourse of the postmodernist ethical thought is given an emphasis to comprehend the ethical thought of postmodern supporters. An understanding of the ethos draws us to a conclusion that reconciliation between postmodernist ethical thought and Islamic spiritual ethics is impossible.
\end{abstract}

Keywords: Ethics, Islam, moral, postmodern, God, Christian

\section{INTRODUCTION}

In the era of Christianity, the practice of understanding nature and God by reason was replaced by faith (Taylor 1985). The seventeenth century saw that the existence of God is characterized by the power of human reason, priority of man before God, independence, self-determination and selfaffirmation. In the nineteenth century, the faculty of reason becomes an instrumental, pragmatic, and practical will to truth. As such, subjectivity has its place while witnessing the occurrence of self- 
destruction and the refusal of man's rights. These brought the world into objectivity that denies the possibility of value, truth and reality. In this respect, it is apparent that modernism gives triumph to man but in turn it requires the death of God. Modernism plays a role in increasing the spread of nihilism, i.e. "the deconstruction of Being, the Being of all beings" including human beings (Levin 1988).

The emergence of postmodernism is regarded as a reaction to modernism, which becomes a challenge to the authority of faith of the medieval period. Postmodernism refuses all the metanarratives of progress to which modernity and modernism have identified themselves with. The term 'postmodern' was first used in the 1950s and 1960s or at an earlier date when architectural criticism designated a movement away from the machine-like austerity of the International Style. The meaning of 'postmodern' was then extended to refer to "reactions against modernism in other branches of art". In the 1970s, the term was used in philosophy as a synonym to deconstruction and poststructuralism (Rée 1993).

In this study, the scope of this study covers a portrayal of the postmodernist outlook on ethics, including whether these ethics are influenced by religion or not. The Islamic perspective on ethics is also presented to provide a comparison between the understandings of ethics from the Islamic point of view as well as from the postmodernist dimension. The direction of this study is to attempt to investigate whether a reconciliation of some sort between postmodernist ethics and Islamic ethics can take place.

\section{SPIRITUAL ETHICAL THOUGHTS IN ISLAM}

History of ethics in Islam is not similar to that of Western history of moral thought. A body of moral guidance, even though it was not properly and systematically organized, governed the life of the early Muslim community. Each community had its own devotional and ethical priorities. They followed the broad traditions of interpretations until the advent of a sophisticated legal theory (al-Ghazali 2001; Donaldson 1963) via the teachings of Islam. Man's perception on ethics changed because Islam not only shows the moral right and wrong from its religious perspective but it also acknowledges customary-based ethics that are not contrary to its teachings.

The arrival of Islam marks an epoch-making event to man's thoughts on ethics. Islam teaches the true spiritual ethics which are derived from the Qur'an and the Prophetic traditions. The traditional practice of Muslims shows that the first and foremost education for children must begin with the study of the Qur'an. It is due to the fact that the Qur'an contains principles on Islamic moral-spiritual ethics alongside with other disciplines of knowledge. Besides the Qur'an, the Prophetic traditions are another major source of Islamic ethical guidance for man. For issues about which both the Qur'an and the Prophetic traditions are silent, Muslims are to use their faculty of reason (Hourani 1985; Sulaiman et al. 2018). Muslim scholars such as al-Ghazali (d.1111) do not deny the importance of using the faculty of reason and its authority to become the source of knowledge. Human reasoning, however, must be in line with both the Qur'an and the Prophetic traditions as these sacred sources of knowledge are superior to reason and not vice versa (Abul Quasem 1975; Donaldson 1963). 
The expansion of Islam enabled its scholars to consolidate the works of the Greeks, to whom Muslim scientific, ethical and religious figures are grateful. The Greek philosophical-moral elements influenced a number of Muslim philosophical-ethical thinkers. Al-Razi (d.925), al-Farabi (d.950), alMiskawayh (d.1030), Ibn Sina (d.1037) and al-Ghazali are a few examples of Muslims who were inclined, with a degree of caution, to Aristotlean ethical philosophy. These scholars refused to be dragged into polemics over the reconciliation of Greek thoughts and Islam (al-Ghazali 2001: 274-275). Muslim philosophers of the 11th and 12th centuries gained more freedom to write philosophical works on ethics (Donaldson 1963). Some promising Islamic ethical literature include Ibn Miskawayh's The Refinement of Character, al-Mawardi's (d.1058) Kitab Adab al-Dunya wa al-Din, al-Ghazali's Revivification of the Sciences of Religion, Fakhr al-Din al-Razi's (d.1209) The Book Soul and Spirit and an Exposition of Their Faculties, Nasir al-Din al-Tusi's (d.1274) Spiritual Physics and Jalal al-Din alDawwani's (d.1502) Akhlaq-i Jalali (Mohd. Nasir 1994; Ibn Miskawayh 1968).

As far as ethics are concerned, it is used as akhlaq in the Qur'an and the Hadith. The word akhlaq is originally derived from its root word khuluq, i.e. character, nature, (natural) disposition and moral constitution, while akhlaq is morals, ethics, character traits, morality or good manners (al-Mawrid 1996). The word akhlaq comes only once in the Qur'an in its singular form, khuluq (al-Ghazali 2001), as the Qur'an says: "And you (Muhammad) are truly a man of noble character" (al-Qur'an 68: 4; Fakhry 2004). Although the word khuluq occurs once, the Qur'an consists of several Islamic ethical principles. Its moral motive is to instill in man his responsibility and relationship with God at its highest meaning (Fakhry 1991).

The Qur'anic passages of ethical principles consist of three fundamental concepts: right and wrong, divine justice and power as well as human freedom and responsibility. Explicit texts and implicit evidences related to ethical responsibility are not sufficient in the Qur'an and this differentiates its ethical thought from the Hadith (Fakhry 1991). Unlike the Qur'an, Hadith is less explicit in terms of its circumstantial and juridical character, which implies its lesser relation with the Qur'anic ethical concepts. Nevertheless, several Hadiths touch upon the questions of right and wrong with no systematic theory of justice and responsibility (Fakhry 1991). Apart from that, many Hadiths are concerned on improving the character, the best-known is to which the Prophet said, "I was sent to perfect good character" (Malik n.d.).

The importance of acquiring noble traits of character was treated in a systematic way during the period of al-Ghazali. According to Ibn Miskawayh, the works of al-Ghazali integrate the philosophicalethical elements into the religious tradition which then becomes dominant among the Sunni Muslims (Ibn Miskawayh 1968). To al-Ghazali, the process of acquiring an exalted character should be alongside the emphasis on the need of instilling strong faith in men as this would shed a light on his character (al-Ghazali 2001; Sulaiman et al. 2014). Furthermore, the attainment of good character is both a condition and a product of the religious life (al-Ghazali 2001). Character is "a state of the soul which causes it to perform its actions without thought or deliberation". The state of the soul is 
acquired by habit and self-training which may gradually become a character trait (Ibn Miskawayh 1968).

In al-Razi's work entitled The Book Soul and Spirit and an Exposition of Their Faculties, he maintained that ethics refers to man's soul (Razi 1981). According to al-Ghazali's philosophical-ethical view, ethics is "a study of certain religious beliefs (i'tiqadat), and of the right and wrong action for the purpose of practice, and not for the sake of mere knowledge. The study of action includes study of actions directed towards God, of man's conduct in family and in social relationships, of purification of soul from vices and of its beautification with virtues" (Abul Quasem 1975). It follows from here that ethics in Islam is all-comprehensive. It covers a three-dimensional code: ethics of man to God as the Creator, ethics of man to human beings and ethics of man to other beings, including animals, plants and the environment.

The Islamic spiritual ethics deal with the study of the qualities of the soul, which inculcate in men excellent character traits and qualities. Its major purpose is to influence man's conduct in order for him to implement the Islamic ethical principles into his daily life (Abul Quasem 1975). Ethics in Islam insists on the consistency of the soul and the character. In fact, the relationship between the character and the soul is well expounded in the writings of Muslim scholars. In his The Refinement of Character, for instance, Ibn Miskawayh contended the necessity of perfecting the soul and the character as the earlier is able to know what is right and what is wrong through its own essence and substance, i.e. reason (Ibn Miskawayh 1968). Al-Tusi's discussion on ethics is mainly taken from Ibn Miskawayh's while al-Dawwani's work is dependent on al-Tusi's (Ibn Miskawayh 1968).

In brief, the principles of the Islamic spiritual ethics are based on the Qur'an and the Hadith. Besides these sacred sources, the principles of Islamic ethics are also grounded in the logical and rational reasons as Islam acknowledges its value to determine matters of moral right and wrong. Nevertheless, the faculty of reason should not be superior to the Qur'an and the Hadith in the Islamic spiritual ethics. Muslim philosophers of spiritual ethics place a great emphasis on the training of the soul. This includes its improvement, purification and perfection as these could be a means for men to achieve an excellent trait of character.

\section{MORAL THOUGHTS IN THE WEST}

The criteria of the right and wrong morals in a society are usually associated with religious prescription, customs, tradition, model figures, family, friends, literature and one's own decision (Hourani 1985). The philosophy of morals is one of the contributions of the ancient people. However, Socrates, Plato, Aristotle's discourse of moral right and wrong seems to be out of a genuine attention. However, the ancient philosophy of morals does not have any distinctive foundation which thoroughly explains what is right and what is wrong (Taylor 1985), what is good and what is bad and what is proper and what is improper. Moral thought has a long history in the West, from the use of experience as a means to comprehend man's place in the world to the employment of the rational mind to answer a range of moral questions. Rational methods of argumentation, according to Socrates, are the true tool to answer any ethical questions while rejecting the value of emotions and norms to determine what a person should or should not do (Velasquez \& Rostankowski 1985). 
Unlike the ancient philosophers who placed much attention on the use of reason to guide man's act, the modern thinkers have a different viewpoint on morals. Modern philosophers contended that morals are the product of the religious tradition, and such a belief was unfamiliar to the former. Although the modern philosophers maintained that morals come from the religious tradition, their treatment towards morals is rather futile. With the exception of a few, the modern philosophers are not consistent in their opinion on moral thoughts. The meaning of morals within the religious perspective is clearly explained by the modern philosophers, but they failed to give an understandable connotation when it is out of the context. Modernism gives reason an ultimate legitimacy and as such, it 'kills' God (Taylor 1985).

According to a modern view, morals should be shaped by culture instead of its total dependence on the faculty of reason. The significance of culture is evident from the theory of sociology, known as cultural relativism. It defines that different cultures have distinctive beliefs about morality. The complexity to answer an ethical question happens when it deals with the philosophical theory, i.e. ethical relativism. According to the theory, different cultures with divergent moral beliefs have no actual way to decide whether an act is morally right or wrong other than asking people of a certain culture a similar question, i.e. is an act morally right or wrong? (Velasquez \& Rostankowski 1985).

As far as postmodernism is concerned, there is no place for a comprehensive definition of postmodernism. People observe it from different angles and define it accordingly. From the epistemological point of view, postmodern is defined as "incredulity towards meta-narratives" (Lyotard 1996). In the literary sense, postmodernism refers to "that movement within contemporary literature and criticism which calls into question the claims of literature and art to truth and human values" (Graff 1998). The distinct context of each perspective illustrates a diversity of elements of postmodernism.

Postmodernism is definitely a problematic term. For some people, postmodernism suggests the death of God and disappearance of religion, for others, the return of traditional faith, and for still others, the possibility of recasting religious ideas (Taylor 1992). Postmodernism is also considered as a response to modernity and to modernism as well. Some people perceive the emergence of postmodernism as to 'replace' modernism (Hassan 1996; Ziauddin 1998). Shomali points out that postmodernism is "a cluster of reactions to modern philosophy and its presuppositions". It is almost difficult among postmodernists to reach any unanimous consensus on any "substantive doctrine" of postmodernism (Shomali 2001). It is assumed that postmodernism takes place as a response to the outlook of modernism which is full of ambiguities, but postmodernism can be ambivalent too. Thus, postmodernists find obstacles to uphold postmodern doctrines and principles.

In the opinion of Skiotis, postmodernism does not substitute modernism. Postmodernism does not come after modernism in terms of historical chronology but as a mere response to a variety of errors in the modern perspective. We still live in a modern period, not in a postmodern era as expressed by postmodernists (Skiotis 2005). His explanation is based on the words of Bauman (1993) who states: 
Postmodern is "post not in the chronological sense (not in the sense of displacing and replacing modernity, of being born only at the moment when modernity ends or fades away, ...) but in the sense of implying (in the form of conclusion, or mere premonition) that the long earnest efforts of modernity have been misguided".

Therefore, postmodernism is not simply an additional epoch or era following modernism, but is inseparably bound to the modern. The term modernism is as complex and contradictory as postmodernism. The meaning of modernism and postmodernism too, changes from context to context and field to field (Taylor 1992). Since postmodernism is regarded as a response to modernism, it is believed that many elements of postmodernism are a continuation of modernism. Dysfunction, deformation, deconstruction, disintegration, critique of reason and the like are criteria of modernism that bridge a link with postmodernism.

The common elements of postmodern philosophy are "anti-epistemological standpoint, antiessentialism, antirealism, anti-foundationalism, opposition to transcendental arguments and transcendental standpoints, rejection of the picture of knowledge as accurate representation, rejection of truth as correspondence to reality, and rejection of principles, distinctions and categories that are thought to be unconditionally binding for all times, persons and places, including a suspicion of metanarratives that (are) illustrated by dialectical materialism" (Magnus 2001). In general, deceiving elements of modernism, for example being anti-spiritual, possessing objective truth, having dominion ethics, etc., show a prolongation in postmodernism. Whether postmodernism comes to replace modernism or to respond to errors in modernism, the continuity of elements of modernism signifies a slight similarity between these two 'isms'. Changes of ethical thought among Western people create confusion, on one hand, and demonstrate a looseness of ethical thought among the people, in a long history, on the other hand. When postmodernism goes against modernism, ethical thought has striven for its survival in a never-ending struggle.

\section{POSTMODERNISM IN RELATION TO RELIGION}

In the age of postmodernism, regardless of the above-mentioned argumentative state of postmodernism, the effort to define religion in the most acceptable sense has come yet to an end. Based on postmodern belief, a defined religion is closely related to what is sacred, transcendental, enchanted and tremendous. In spite of questing for that so called sacred, transcendental, enchanted and tremendous religion, postmodernists cast off eschatological aspects (Bauman 1998). It denotes that life after death has nothing to do with postmodernist thought. Life is presented to be in accordance with the worldly inclination of the postmodernists, solely for their joy and happiness. Life after death thus seems to have lost its credibility.

Dating back to Christian theological faith, it implicitly reserves monotheistic features, on one hand, and acknowledges binary elements, on the other hand. Owing to that, postmodernist religious thought deserves to contain many puzzling ideas, including its ethical thought. The table describes the selected contradictory movement of religious thought in Western history (Taylor 1996): 
INTERNATIONAL JOURNAL OF ACADEMIC RESEARCH IN BUSINESS AND SOCIAL SCIENCES Vol. 9, No. 1, Jan, 2019, E-ISSN: $2222-6990$ (c) 2019 HRMARS

\begin{tabular}{|c|c|}
\hline God & World \\
\hline Eternity & Time \\
\hline Being & Becoming \\
\hline Rest & Movement \\
\hline Permanence & Change \\
\hline Presence & Absence \\
\hline One & Many \\
\hline Sacred & Profane \\
\hline Order & Chaos \\
\hline Meaning & Absurdity \\
\hline Life & Death \\
\hline Infinite & Finite \\
\hline Transcendent & Immanent \\
\hline Identity & Difference \\
\hline Affirmation & Negation \\
\hline Truth & Error \\
\hline Reality & Illusion \\
\hline Certainty & Uncertainty \\
\hline Clarity & Confusion \\
\hline Sanity & Madness \\
\hline Light & Darkness \\
\hline Vision & Blindness \\
\hline Invisible & Visible \\
\hline Spirit & Body \\
\hline Spiritual & Carnal \\
\hline Mind & Matter \\
\hline Good & Evil \\
\hline Innocence & Guilt \\
\hline Purity & Stain \\
\hline Proper & Improper \\
\hline Centered & Eccentric \\
\hline First & Second \\
\hline Original & Imitation \\
\hline Natural & Monstrous \\
\hline Purposeful & Purposeless \\
\hline Honesty & Duplicity \\
\hline Height & Depth \\
\hline Depth & Surface \\
\hline Interiority & Exteriority \\
\hline Speech & Writing \\
\hline Seriousness & Play \\
\hline
\end{tabular}


The contradictory movement of the religious thought has notable impacts on the ethical thought of postmodernists. Religion is separated from ethics that develops an ethical thought without any religious principles. The dichotomy is sustained among postmodernists regardless of some postmodern thinkers, who theoretically and practically observe religion, and reject all the oppositional terms. Postmodernism irrefutably favours the idea of dualism as it "affirms the existence of irreconcilable value systems and the existence of irreconcilable ontological and epistemological understandings" (Rahman 1994).

Postmodernists renounce any idea to bring religious values together with moral values. Human conduct is not in agreement with morality and an all-comprehensive unitary ethics does not exist to serve the people. Epistemology, likewise, according to postmodernists, is not in agreement with metaphysical dimension. Perhaps metaphysics possesses an incapability to comprehend the epistemological discourse. In short, postmodernists give no room for God, religion and related matters. For God and religion to be present together with worldly activity is impossibility.

\section{POSTMODERNIST ETHICAL THOUGHT: A REVIEW}

Ancient Western people observed ethics as a custom. In the Christian period, the church transformed those customary ethics into an ethics of duty to God. Modern age, on one hand, has attempted to retain the thought of moral right and wrong, and puts God aside, on the other hand (Taylor 1985). The beginning of modernism brings religion to a halt. Western people have a vague mind about God, i.e. God's nature and existence. Modernism promotes a fragmented life of individuals and a nonunitary vision of the world (Bauman 1993). Modern ethical thought and moral practice are animated by a conviction in the possibility of a non-ambivalent, non-aporetic ethical code, but it has yet to be found (Bauman 1993).

Modernity suggests ethics without God or religion. An action is done for the enthusiasm of worldly life. Morality, in postmodernist ethical thought, is believed to be as a moral responsibility rather than as a duty to moral codes. Morality cannot rely on a limited set of rules whilst moral responsibility is endless (Skiotis 2005). Besides new postmodernist ethical elements, other aspects of postmodernism show a kind of similarity, to some extent, with modernism. A dualistic approach to ethics goes after postmodernism as postmodernists suggest the irreconcilability between religion and ethics. The postmodernist ethical thought goes beyond dualism.

Ethical thought has no place in postmodernism because postmodernist ethical thought can generally be understood as the death of ethics in all human worldly activities. Actions are free from a sound rule-based ethics as Bauman states (Bauman 1993):

What has come to be associated with the notion of the postmodern approach to morality is all too often the celebration of the 'demise of the ethical', of the substitution of aesthetics for ethics, and of the 'ultimate emancipation' that follows. Ethics itself is denigrated and derided as one of the typically modern constraints now broken and destined for the dustbin of history. 
As an anti-eschatological revolution, postmodernist ethical thought does not take rewards or punishment on the Day of Judgement into consideration. Postmodernism rejects religious values, metaphysics, genuine epistemology and incredulity toward metanarratives in knowledge. Thus, postmodernist truth is uncertain and not easily understood. By rejection of the sorts of universal truth which are characterized by a complicated state of some universal or absolute values, knowledge becomes meaningless due to the absence of a method (Shomali 2001).

As Western people are in search for the most appropriate definition for religion, it implies two points of view: postmodernist ethical thought is not grounded by religious principles, and God as well as religion are not part of it. It is in conformity to Bauman's proposition as he denotes "not all strategies of human being in the world must be ultimately religious". Religion is not superior in relation to ethics. Without a doubt, religion has little position in the process of rational adjustment (Bauman 1998). For an action to be determined as good or bad, the capacity of reason is larger than religion. For postmodernist ethical thought, religion is meaningless and useless for ethics.

In spite of the significance of reason, moral-ethical values cannot be resolved, nor the moral life of humanity guaranteed, by the calculating and legislative efforts of reason. In a contradictory affirmation, Bauman states that morality and ethics are not safe in the hand of reason. In the end of a long march of morality, moral nihilism awaits to supersede it, and thus morals are lost (Bauman 1993). In the light of Bauman's points of view, the marks of moral condition and ethical state from the postmodern perspective are as follows (Bauman 1993):

1. Humans are morally ambivalent and thus no sound ethical code can go well with the ambivalent condition of morality.

2. Moral phenomena are irrational. Neither they can be represented as 'rule-guided' nor reduced to any universal ethical codes.

3. Morality is incurably aporetic. Every moral impulse, if acted upon in full, leads to immoral consequences. The moral self moves, feels, and acts in the context of ambivalence and uncertainty.

4. Morality is not universal. It goes against the substitution of heteronomous, enforced-fromoutside, ethical rules for the autonomous responsibility of the moral destruction, of the moral self.

5. Morality is bound to remain irrational, i.e. morality cannot be grounded in reason but in moral impulse.

6. Moral responsibility is the first reality of the self. With no foundation, a human relationship is built on power and force, instead of love and passion.

7. A postmodern perspective shows a relativity of ethical codes and moral practices. In other words, the ethical codes are plagued with relativism.

Based on its nature, rejection of postmodernism of a rule-guided ethics implies an implication to postmodernist ethical thought. Postmodernist ethical thought is ambivalent, aporetic and uncertain, and is also irrational and full of relativism. It is also neither insufficient nor universal. Each character 
is related to one another. As modernism has not finished finding a non-ambivalent ethical code, postmodernism that reacted to misguided doctrines of modernism prolongs the ambiguous ethics. For postmodernism, certainty has no place in ethics. Uncertainty is the ground of moral choice, and of moral responsibility (Bauman 1993).

Apart from continuing the doctrines of modernism, postmodernism suggests an ambivalent, aporetic morality and a non-universal and not objectively founded ethics (Bauman 1993). According to postmodernism, insufficiency is created by religion, thus, religion must be cast to give man selfsufficiency. By self-sufficiency, man's brainpower and strength are capable to do things and to comprehend everything. Self-sufficiency suggests man's action without God. It is a total human order of the worldly life that excludes God, transcendental and supernatural existence, and the afterlife. Human self-sufficiency undermines the grip of institutionalized religion not by promising an alternative way to eternal life, but by drawing human attention away from it (Bauman 1998). It is inter-related to humanism which suggests "man as the 'shepherd' of Being rather than its engineer or overseer" (Heidegger 1996). With self-sufficiency and humanism, man becomes an autonomous being; thus, he does not need God and religion in his daily activities.

Postmodernism is likely associated with and supports relativism, i.e.: the denial of certain kinds of universal truth (Shomali 2001). Postmodernism rejects any type of universal truth in ethics. In the attempt to bridge a link between the uniqueness of truth and that of disparate visions of truth as true, postmodernism promises liberation from domination of one vision of truth by another (Rahman 1994). Relativism regards social construction as determining something to be considered "good" (Shomali 2001). In respect to ethical relativism, it is "a cluster of doctrines arising from reflections on differences in ethical belief across time and between individuals, groups, and societies". It suggests "there are no universal valid moral principles; the validity of all moral principles is relative to culture or individual choice" (Shomali 2001).

Relativism is not applicable to Islamic spiritual ethics which are guided by a set of religious-customary principles. While the external elements applied onto human life change in accordance with the ongoing changes, the Islamic fundamental principles of ethics that underpin these elements remain. The ambiguity of the theory of ethical relativism led to its rejection by many present Western philosophers as stated by Shomali "unlike in the late nineteenth and early twentieth, interest in ethical relativism has recently declined" (Shomali 2001). Postmodernist thought of ethical relativism implies a subjectivity of moral right and wrong; it changes by the transition of time, place, individuals and societies. It suggests a relativity of moral right and wrong of a different time and place.

Overall, the review shows the incompatibility between postmodernist Western ethical thought and Islamic spiritual ethics. In Islam, worldly deeds are for the life in the Hereafter. Man has to do what is morally right and wrong primarily based on the religious precepts of God. God, religion and reason have a considerable meaning in ethics. Islamic spiritual ethics are laid in a sound, uncomplicated foundation of moral-spiritual ethics. Islamic rule-guided ethics give man self-sufficiency, but only to a certain extent as the created. Islam recognizes relativism, but with a great caution; some elements 
INTERNATIONAL JOURNAL OF ACADEMIC RESEARCH IN BUSINESS AND SOCIAL SCIENCES

Vol. 9, No. 1, Jan, 2019, E-ISSN: 2222-6990 (C) 2019 HRMARS

may change while other elements remain unchanged. In general, religion is the main course of Islamic spiritual ethics. Religion certainly has significance to ethics as Taylor states that indeed ethics cannot attain their meaningfulness without a religious framework (Taylor 1985).

\section{CONCLUSION}

As a conclusion, reconciliation between postmodernist ethical thought and Islamic spiritual ethics is an impossibility based on these key points:

1. The rejection of metaphysical thought and religion in postmodernism denotes the 'nonexistence' of God. Thus, the 'death of God' might be true as postmodernists deny God's presence and intrusion in any of their activities.

2. The atheistic approach of postmodernism to religion retains the idea that God is dead. In this approach, God is manifested as a reflection of the supernatural human mind due to the failure to understand the concept of God.

3. The doctrine of nihilism gradually reduces the meaning of values and dissolves values in an absolute sense. By nihilism, values are neither based on traditional metaphysical thought nor on the concept of God.

4. Postmodernism supports relativism in total as well as ethical relativism. It strongly opposes an exclusive, transcendent and objective truth.

The imprecise elements of postmodernism show a disproportionate way of ethics of the West. Postmodernist ethical thoughts are definitely different from Islamic spiritual ethics; the latter having a clear foundation of ethics. Thus, we might say that postmodernist ethical thoughts and Islamic spiritual ethics can never be reconciled. Reconciliation between the two-absolute contradictory ethical ideas can never be achieved. The Islamic spiritual ethics is religious and sacred whilst postmodernist ethical thought is highly concerned with the human good of the worldly life. Furthermore, principles of ethics as outlined in the Islamic tradition are open-ended. In this respect, postmodernism becomes a predicament for its weird ideas. These ideas may affect Muslims' political, economic, social and spiritual aspects of thought, action, behaviour and ethics.

\section{ACKNOWLEDGEMENT}

This study is funded by the University Short-Term Research Grant (PPP/USG0216/FPBU/PPT/30/18416), Universiti Sains Islam Malaysia.

\section{REFERENCES}

Abul Quasem, M. (1975). The Ethics of al-Ghazali. n.pp.: n.np.

Al-Ghazali. (2001). Al-Ghazali on Disciplining the Soul Kitab Riyadat al-Nafs \& On Breaking the Two Desires Kitab Kasr al-Shahwatayn. Trans. Winter, T.J. Cambridge: The Islamic Texts Society.

Anon. (1996). al-Mawrid. Beirut, Lebanon: Dar al-'Ilm li al-Malayin. 
INTERNATIONAL JOURNAL OF ACADEMIC RESEARCH IN BUSINESS AND SOCIAL SCIENCES

Vol. 9, No. 1, Jan, 2019, E-ISSN: 2222-6990 (C) 2019 HRMARS

Anon. (1997). The Cassell Concise Dictionary. London: Cassell.

Audi, R. (Ed.). (2001). The Cambridge Dictionary of Philosophy. Cambridge: Cambridge University Press.

Bauman, Z. (1993). Postmodern Ethics. Oxford: Basil Blackwell Ltd.

Bauman, Z. (1998). Postmodern religion?. In Heelas, P. et al. (Ed.). Religion, Modernity and Post Modernity (pp. 55-78). Oxford: Blackwell Publishers Ltd.

Donaldson, D.M. (1963). Studies in Muslim Ethics. London: S.P.C.K.

Fakhry, M. (1991). Ethical Theories in Islam. Leiden: E.J. Brill.

Fakhry, M. (2004). An Interpretation of The Qur'an. New York: New York University Press.

Graff, G. (1998). The myth of postmodernist breakthrough. In Taylor, V.E. \& Winquist, C.E. (Eds.). Postmodernism: Critical Concepts (pp. 121-145). London: Routledge.

Hassan, Ihab. (1996). Postmodernism: A paracritical bibliography. In Cahoone, L.E. (Ed.). From Modernism to Postmodernism: An Anthology (pp. 382-400). Cambridge: Blackwell Publishers Inc.

Heidegger, M. (1996). Letter on humanism. In Cahoone, L.E. (Ed.). From Modernism to Postmodernism: An Anthology, (pp. 274-308). Cambridge: Blackwell Publishers Inc.

Hourani, G.F. (1985). Reason and Tradition in Islamic Ethics. Cambridge: Cambridge University Press.

Ibn Miskawayh. (1968). The Refinement of Character. Trans. Zurayk, C.K. Beirut: Centennial Publications.

Levin, D.M. (1988). The Opening of Vision: Nihilism and The Postmodern Situation. New York: Routledge.

Lyotard, J. \& Lyotard, F. (1996). The postmodern condition: A report on knowledge. In Cahoone, L.E. (Ed.). From Modernism to Postmodernism: An Anthology, (pp. 481-513). Cambridge: Blackwell Publishers Inc.

Magnus, B. (2001). Postmodernism. In Audi, R. (Ed.). The Cambridge Dictionary of Philosophy. Cambridge: Cambridge University Press.

Rahman, A.F.A. (1994). Coming to grips with postmodernism. Journal IKIM 2(2), 58-74. 
INTERNATIONAL JOURNAL OF ACADEMIC RESEARCH IN BUSINESS AND SOCIAL SCIENCES

Vol. 9, No. 1, Jan, 2019, E-ISSN: 2222-6990 (C) 2019 HRMARS

Razi, I. (1981). Imam Razi's 'llm al-Aklhaq. Trans. M. Saghir Hasan Ma'sumi. New Delhi: Kitab Bhavan.

Sardar, Z. (1998). Postmodernism and The Other: The New Imperialism of Western Culture. London: Pluto Press.

Shomali, M. A. (2001). Ethical Relativism: An Analysis of the Foundations of Morality. London: Islamic College for Advanced Studies Press.

Skiotis, P. (2005). Postmodern ethics: A Buddhist response, http://www.westernbuddhistreview.com/vol14/postmodern_ethics.html, 22 February, 1-13.

Sulaiman, A., Nizah, M.A.M. \& Norawavi, A.N. (2018). Adab sebagai instrumen penilaian pembelajaran interaktif [Adab as assessment instrument in interactive learning]. e-Proceeding International Conference on Civilisation, Ethnicity and Islamic Heritage (i-STET 2018), pp. 361-368.

Sulaiman, A., Jamsari, E.A. \& Noh, N.C. (2014). Islamic environment in child development according to the views of Imam al-Ghazali. Mediterranean Journal of Social Sciences 5(29), 33-39.

Taylor, M.C. (1992). Reframing postmodernisms. In Berry, P. \& Wernick, A. (Ed.). Shadow of Spirit: Postmodernism and Religion, (pp. 11-29). London: Routledge.

Taylor, M.C. (1996). Erring: A postmodern theology. In Cahoone, L.E. (Ed.). From Modernism to Postmodernism: An Anthology, (pp. 514-533). Cambridge: Blackwell Publishers Inc.

Taylor, R. (1985). Ethics, Faith and Reason. New Jersey: Prentice-Hall Inc.

Urmson, J.O. \& Rée, J. (Ed.). (1993). The Concise Encyclopedia of Western Philosophy and Philosophers. London: Routledge.

Velasquez, M. \& Rostankowski, C. (Ed.). (1985). Ethics: Theory and Practice. New Jersey: Prentice-Hall Inc. 